\title{
XXX. Notice of some new minerals
}

\author{
Thomas Thomson M.D. F.R.S. L. \& E. M.R.I.A.
}

To cite this article: Thomas Thomson M.D. F.R.S. L. \& E. M.R.I.A. (1843) XXX. Notice of some new minerals, Philosophical Magazine Series 3, 22:144, 188-194, DOI: $\underline{10.1080 / 14786444308636349}$

To link to this article: http://dx.doi.org/10.1080/14786444308636349

曲 Published online: 01 Jun 2009.

Submit your article to this journal $\pi$

Џ Article views: 4

Q View related articles ¿ 
pendent, so that equations may be framed that shall satisfy them all.

We cannot infer therefore that there are always as many pairs of imaginary roots as there are conditions fulfilled, although it is probable that there does exist a connexion between the number of conditions and the number of imaginary pairs. But this is a matter that requires further investigation.

Belfast, Jan. 13, 1843.

[To be continued.]

XXX. Notice of some nero Minerals. By Thomas Thomson, M.D., F.R.S. L.\&E., M.R.I.A., \&c., Regius Professor of Chenistry in the University of Glasgow*.

$\mathrm{NE}$ of the most abundant and important minerals is felspar, which constitutes the principal constituent in granite and gneiss, and together with hornblende forms the rocks so prevalent in this part of Scotland, I mean greenstone and basalt. Felspar is a double salt, being composed of 3 atoms of tersilicate of alumina and 1 atom of tersilicate of potash. Sometimes the potash is replaced by soda. The mineral in that case is distinguished by the name of albite, and differs in the shape of its crystals; three of the minerals which I mean to notice at present are connected with felspar, though they differ from it in their composition.

1. Erythrite.-The first species which I shall mention is erythrite. It occurs rather abundantly in the Kilpatrick hills, and also in the amygdaloid on the south side of the Clyde near Bishoptown. I do not know who first noticed it, but it was brought to me some years ago as a new mineral by $\mathrm{Mr}$. Clackers, a mineral dealer in Old Kilpatrick. I call it erythrite, on account of the flesh-red colour which distinguishes all the specimens which I have seen.

Its specific gravity is about 2.511 , which agrees with that of common felspar. And its hardness is about the same as that of felspar; the texture is compact, or at least not sensibly foliated, and $I$ have never seen a specimen of it in crystals. It is composed of

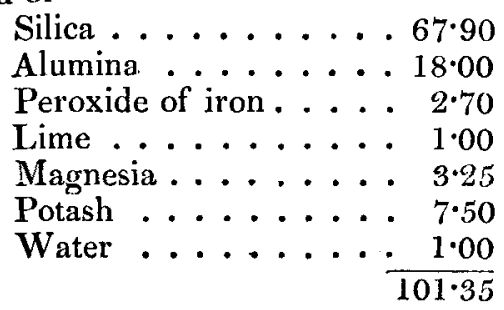

* Read before the Glasgow Philosophical Society, 2nd of November 1842 , and now communicated by the Author. 


$$
\begin{aligned}
& 7\left(\mathrm{Al} \mathrm{S}^{3}\right)+\mathrm{Mg} \mathrm{S}^{3}+\mathrm{KS}^{3} \\
& \text { Pyroxene Cal } \mathrm{S}^{2}+\left(\frac{2}{3} \mathrm{Mg}+\frac{1}{5} f\right) \mathrm{S}^{2} \\
& \text { Amphibole Cal } \mathrm{S}^{3}+3 \mathrm{Mg} \mathrm{S^{2 }} \text {. }
\end{aligned}
$$

So that it differs from felspar by one-half of the potash being replaced by magnesia.

2. Perthite. -The next mineral I have to notice I distinguish by the name of Perthite. It was sent me by Mr. Wilson, a surgeon in Perth, a township of Upper Canada; hence the name by which $I$ have distinguished it. It is very much connected with felspar in appearance, and was sent as a variety of that mineral.

The colour of the specimen sent me is white : it consists of a mass of crystals so united together as to form a kind of tesselated pavement. The crystals are obviously four-sided prisms, apparently rectangular, but not susceptible of measurement, because they cannot be isolated.

The lustre is vitreous; the hardness is rather less than that of felspar; but the specific gravity, which is 2.586 , is identical with that of some of the varieties of that mineral. Its constituents were found to be

$$
\begin{aligned}
& \text { Silica ...... } 76^{\circ} \\
& \text { Alumina . . . . . 11.75 } \\
& \text { Magnesia .....11.00 } \\
& \text { Protoxide of iron . } 0.225 \\
& \text { Moisture . . . } \frac{0.65}{99.625}
\end{aligned}
$$

From this analysis it is evident that it differs essentially from felspar; the quantity of silica is much greater, and the potash is entirely replaced by magnesia. Its constitution may be represented by the formula $6\left(\mathrm{Al} \mathrm{S}^{4}\right)+5\left(\mathrm{Mg} \mathrm{S}^{4}\right)$. It is a quatersilicate, while felspar is a tersilicate. Could it be procured in sufficient quantity it would be an excellent material for the manufacture of porcelain.

3. Peristerite*.-The next mineral which I have to mention was sent me also from Perth in Upper Canada, by Mr. Wilson, and also by Dr. Holmes of Montreal, under the name of Iridescent felspar; but neither its characters nor its composition correspond with that appellation.

The specimens were amorphous masses, and had the appearance of having constituted part of a rock blasted by gunpowder.

It is light brownish red, and exhibits a play of colours, chiefly blue, on the surface. It is translucent on the edges;

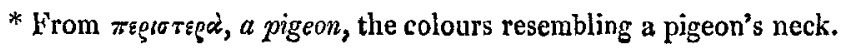


the lustre is vitreous and the texture imperfectly foliated: its hardness is only 3.75 , which is a good deal less than that of felspar. Its specific gravity is $2 \cdot 568$.

Before the blowpipe it becomes white but does not melt. With carbonate of soda it melts into a green coloured bead, and on adding nitre the colour becomes red: with borax it fuses into a colourless bead.

Its constituents were found to be

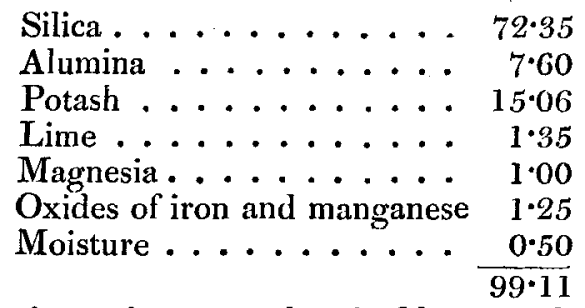

The silica is much greater than in felspar, and the alumina much less, while the proportion of potash is nearly the same. If we were to consider the lime and magnesia and the oxides of iron and manganese as accidental bodies united to silica in the same ratio as the alumina and the potash, the constitution of the mineral might be represented by $4(\mathrm{Al} \mathrm{S})+3\left(\mathrm{~K} \mathrm{~S}^{5}\right)$. If the lime and magnesia be essential constituents, the formula will be $\mathrm{Al} \mathrm{S}^{5}+\left(\frac{6}{8} \mathbf{K}+\frac{1}{8} \mathrm{Cal}+\frac{1}{8} \mathrm{Mg}\right) \mathrm{S}^{5}$.

4. Silicite.-The fourth mineral which I shall notice I have distinguished by the name of Silicite, from the great resemblance which it has to quartz in its external aspect, thougb it differs entirely from that mineral in its constitution. It occurs in a basaltic rock in the county of Antrim, and was given me by Mr. Doran, an Irish mineral dealer.

The colour is white with a shade of yellow, the texture foliated, and the fracture small conchoidal. Its lustre is vitreous, its hardness nearly the same as that of quartz, and its specific gravity $2 * 666$, or nearly the same as that of rock crystal.

With carbonate of soda it fuses into an opake bead, and with borax into a transparent colourless bead. Its constituents are

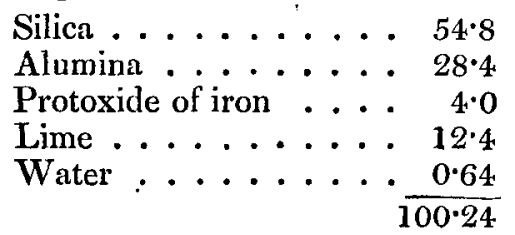

If we suppose the oxide of iron to be combined with alumina and to be only accidentally present, the constitution of silicite will be $7\left(\mathrm{Al} \mathrm{S}^{2}\right)+2(\mathrm{Cal} \mathrm{S})$. 
It is a double anhydrous aluminous silicate. It differs from fuller's earth by containing 2 (Cal S) instead of $2 \mathrm{Aq}$.

5. Gymnite. - To the fifth mineral species which I mean to notice at present $I$ have given the name of Gymnite, because its locality is the bare hills west of Baltimore. I got the specimen in my collection from Mr. Alger of Boston, well known for his and Mr. Jackson's excellent geological description of Nova Scotia.

The mineral was in amorphous pieces, having a very pale and dirty orange colour. It is translucent on the edges; the lustre is resinous. It is very tough and difficult to break: this makes it difficult to determine the hardness; but it is softer than felspar. The specific gravity is $2 \cdot 2165$. When held in the flame of a spirit-lamp it becomes dark brown: with soda it fuses into a white opake bead; with borax into a colourless bead; with nitrate of cobalt it assumes a rose-red colour. be

Being subjected to analysis, its constituents were found to

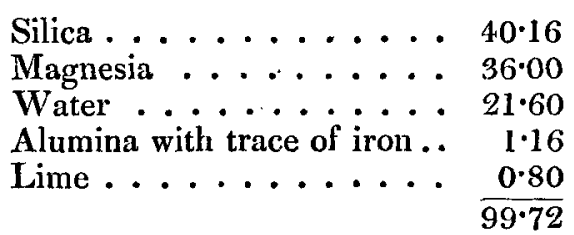

It is therefore composed of silica, magnesia and water, and its constitution may be represented by the formula $2(\mathrm{Mg} \mathrm{S})$ $+\mathrm{Mg} \mathrm{S}+4 \mathrm{Aq}$.

6. Baltimorite.-For the next mineral species which I mean to notice I am also indebted to Mr. Alger. The specimen was labelled Asbestus with chrome, and the locality Baltimore; on this account I have given the species the name of Baltimorite.

The colour is grayish-green. The mineral is composed of longitudinal fibres, adhering to each other, and has a considerable resemblance to asbestus; the lustre is silky. The mineral is opake; but when very thin it is translucent on the edges. It is a very little softer than calcareous spar. It does not fuse before the blowpipe, but assumes a brown colour. With soda melts into an opake, and with borax into a transparent bead. Its constituents are

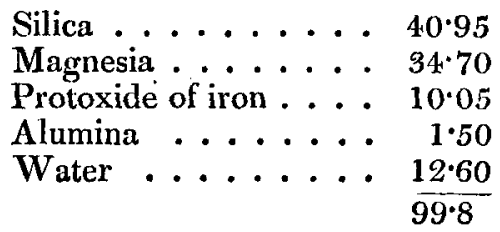


Its constitution may be represented by the formula

$$
\text { 14. }(\mathrm{Mg} \mathrm{S})+3\left(\frac{3}{4} f+\frac{1}{4} \mathrm{Al}\right) \mathrm{S}^{2}+11 \mathrm{Aq} \text {. }
$$

Asbestus contains more silica and a good deal of lime, which is wanting in baltimorite: asbestus, in fact, is merely a variety of pyroxene.

7. For the next mineral, which from its constitution I call subsesquisulphate of alumina, I am also indebted to Mr. Alger. The locality is South Peru.

It is a soft, opake mineral, composed of silky fibres adhering to each other. The colour is white, but there is a reddish yellow tint which partially pervades the specimens, owing obviously to a little foreign matter with which they are stained. The taste is acid and sweet, like that of alum. 'The specific gravity is 1.584 . It is soluble in water. The constituents are

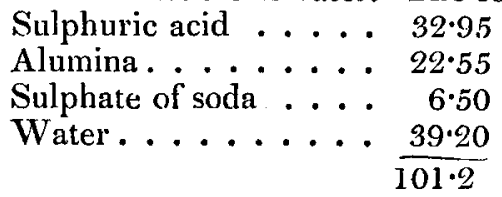

Obviously, I atom of sulphuric acid ... 5.

$1 \frac{1}{2}$ atom of alumina ..... 3.375

1 atom of sulphate of soda . . $9 \cdot 0$

5 atoms of water ..... 5.625

$$
23 \cdot
$$

'The sulphate of soda exists in a greater proportion than sulphate of potash or of ammonia does in our alum. It is curious that in South America soda almost universally replaces the potash which occurs in other parts of the world. Instead of saltpetre, so abundant in India and even in Europe, we have nitrate of soda in Peru, and instead of potash alum, we find in Buenos Ayres and other districts of South America, soda alum deposited in amygdaloidal cavities in a kind of shale.

8. Messrs. Alger and Jackson gave the name of Acadiolite to a variety of chabasite which they found in Nova Scotia, and specimens of which Mr. Alger was kind enough to send to me. The colour of the mineral is yellow, and it has the crystalline shape and the characters of chabasite so completely, that it would be considered as a mere variety of that mineral were it not that the constituents do not quite agree. The specific gravity of acadiolite is 2.0202 , and its constituents,

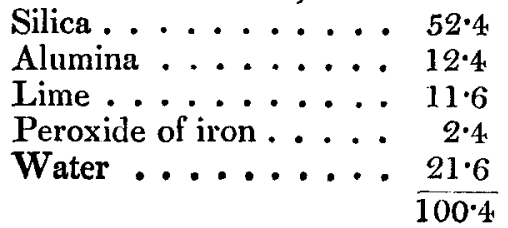


The proportion of alumina in chabasite is greater than in acadiolite. If this difference be constant acadiolite must be considered as a new species. Its constitution, and that of chabasite, may be represented by the formulas-

$$
\begin{aligned}
& \text { Acadiolite } \ldots 2\left(\mathrm{Al} \mathrm{S}^{3}\right)+\mathrm{Cal} \mathrm{S}^{2}+6 \mathrm{Aq} \text {. } \\
& \text { Chabasite } \ldots 3\left(\mathrm{Al} \mathrm{S} \mathrm{S}^{2}\right)+\mathrm{Cal} \mathrm{S}^{3}+6 \mathrm{Aq} \text {. }
\end{aligned}
$$

9. Prasilite.-To the next mineral species which I shall mention I have given the name of Prasilite, from the green colour by which the only specimen which $I$ have seen is characterized. It is found in the Kilpatrick hills, and was brought to me some years ago by a gentleman while attending my class. He had picked up the specimen and brought it that I might tell him its name. On looking at and examining its hardness and texture, I pronounced it to be sulphate of lime tinged by an admixture of epidote; but upon examining it chemically, I soon discovered that the opinion formed from its external character was erroneous.

The colour is dark leek-green, and the hardness not more than I; for it does not scratch selenite. It is opake, and has a specific gravity of 2.311 , which comes near to that of selenite. It may be crumbled to powder between the fingers. It is composed of fibres very loosely adhering together. When heated to redness it gives out 18 per cent. of water, assumes a light yellow colour, and becomes much harder. Being subjected to analysis, its constituents were found,-

$$
\begin{aligned}
& \text { Water ....... 18.00 } \\
& \text { Silica ........ 38.55 } \\
& \text { Magnesia . . . . . 15.55 } \\
& \text { Lime ......... 2.55 } \\
& \text { Peroxide of iron . . . 14.90 } \\
& \text { Oxide of manganese .. } 1.50 \\
& \text { Alumina ..... } \frac{5 \cdot 65}{96 \cdot 70}
\end{aligned}
$$

The loss, amounting to 3 per cent., was probably an alkali. Prasilite is obviously a triple sesquisilicate. Its constitution may be represented by the formula

$$
8\left(\mathrm{Mg} \mathrm{S}^{1 \frac{1}{2}}\right)+4\left(f \mathrm{~S}^{1 \frac{1}{2}}\right)+3\left(\mathrm{Al}^{\mathrm{N}} \mathrm{S}^{1 \frac{1}{2}}\right)+18 \mathrm{Aq} \text {. }
$$

10. The next mineral which $I$ shall notice is one which occurs in the beds of iron ore at Franklin in New Jersey, and was first noticed by Messrs. Keating and Vanuxem about the year 1822, under the name of Jeffersonite. Keating made an analysis of it, the result of which induced me to place it among the magnesian minerals, and intimately connected with pyroxene and amphibole. But having got a specimen of it through the kindness of Dr. Torrey of New York, I subjected Phil. Mag. S. 3. Vol.22. No. 144. March 184.3. 


\section{Prof. Kelland on Mr. Earnshaw's Reply to the}

it to a new analysis. The result was so different from $\mathrm{Mr}$. Keating's, that it became evident that the position which I had assigned it was a wrong one, and that in reality it was a quadruple salt consisting of silica united to the four bases, lime, alumina, iron, and magnesia.

The colour of Jeffersonite is dark olive green, passing into brown. It is foliaterl, and according to Keating, may be cleaved in various directions. The specimen in 'my possession is an imperfect four-sided prism; but the faces are not smooth enough to admit of measurement.

The lustre is resinous and almost semimetallic; the streak is gray, and the powder light green. It is rather harder than fluorspar, though softer than apatite. The specific gravity is 3.51. Before the blowpipe it fuses readily into a dark coloured globule : its constituents are

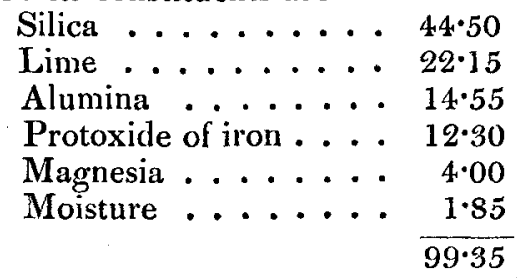

The constitution may be represented by the formula $4($ Cal S $)+4($ Al S $)+2\left(f \mathrm{~S}^{2}\right)+\mathbf{M g ~ S}$

so that it differs essentially in its composition from both pyroxene and amphibole.

XXXI. On Mr. Earnshaw's Reply to the Defence of the Nerotonian Law of Molecular Action. By the Rev. P. KeLland, M.A., F.R.SS. L. \& E., \&c., Professor of Mathematics in the University of Edinburgh**

O $\mathrm{N}$ receiving the Philosophical Magazine for December, 184.2, in which Mr. Earnshaw terminates his Reply to me by requesting an.answer to four questions, I thought it right not to delay complying with his request. But I am not, of course, hindered thereby from discussing the rest of his paper. In point of fact, I am in arrear two answers to Mr. Earnshaw, viz. to part of his paper in the November Number, and to that before me. I do not, however, see that the former of these requires any rejoinder. I admit the first and second remarks in it, understood of relative, not of absolute displacements, but do not see that they bear on the question before us. To the third remark I have already replied.

Let me then confine myself to the last paper, and examine

* Communicated by the Author. 